\title{
Assessing emerging beef farmers participation in high-value market and its impact on cattle sales in South Africa
}

\author{
O.S. Oduniyi ${ }^{*}$ (iD), M.A Antwi ${ }^{2}$ and A.N. Mukwevho 3 \\ Received 6 July 2021, Revised 20 October 2021, Accepted 20 December 2021, Published online 31 December 2021
}

\begin{abstract}
A B S T R A C T
The participation of emerging farmers in high-value agricultural markets in South Africa cannot be over-emphasized. It is one of the objectives of the government to assist emerging farmers with the necessary resources and programmes to enable them to meet the requirements and participate in high-value markets. The study investigated the impact of participation in the high-value market on cattle production (cattle sold). A systematic random probabilistic sampling technique was used to obtain a sample of 55 emerging beef farmers. Interviews were undertaken using questionnaires to collect data. Descriptive statistics and econometric methods such as Tobit model and a treatment effect model using propensity score matching estimator were employed for the data analysis. The results of binary logit regression from the PSM revealed that participation in a high-value market was significantly affected by age, household size, years of farming and difficulty accessing a highvalue market. The average treatment effect of the treated showed a negative impact and decreases the number of cattle sold by $58 \%$. The recommendations informed by the findings from the study are that youth in the study area should be involved in beef farming, appropriate training should be given to the farmers and farmer's advisor should motivate farmers to sell more cattle and participate in a high-value market, and educate them about the requirements to participate in the high value markets. The DARD lease assistance should continue and include the lease of more land.
\end{abstract}

Keywords: Emerging farmers, Market access, High-value agricultural market, Propensity score matching, Tobit regression model, South Africa

${ }^{I}$ PhD (Agricultural Economics) University of South Africa, Department of Agriculture and Animal Health. Florida Campus ${ }^{2} \mathrm{PhD}$ (Agricultural Economics) University of South Africa, Department of Agriculture and Animal Health. Florida Campus ${ }^{3}$ Msc (Agricultural Economics) University of South Africa, Department of Agriculture and Animal Health. Florida Campus

*Corresponding author's email: eodunios@unisa.ac.za (O.S. Oduniyi)

Cite this article as: Oduniyi, O.S., Antwi, M.A. and Mukwevho, A.N. 2021. Assessing emerging beef farmers participation in high-value market and its impact on cattle sales in South Africa. Int. J. Agril. Res. Innov. Tech. 11(2): 27-36. https://doi.org/10.3329/ijarit.v11i2.57252

\section{Introduction}

Globally, livestock contributes $15 \%$ of the total food energy and $25 \%$ of dietary proteins (FAO, 2012). Agriculture plays an important role in South Africa as it contributes significantly to the country's Gross Domestic Product (GDP), employment, rural development and food security (Antwi et al., 2016). The livestock sector is one of the fastest-growing sectors of an agricultural economy driven by income growth and supported by technological and structural change (Anonymous, 2012). The sector contributes $40 \%$ of the global value of agricultural output and supports their livelihoods and food security, almost a billion people (FAO, 2019). Beyond its role in creating food and income, livestock is regarded as an asset, serving as wealth and collateral for credit, which is essential security during net calamitous times. Agriculture alone plays a major role in creating job opportunities especially for people living in rural areas; it also helps in poverty alleviation. Markelova et al. (2009) supports this by saying that the agricultural sector has the potential to create economic growth in rural areas.

Equally, livestock farming in South Africa is the only viable agricultural activity in a large part of the country. Approximately 80\% of South African agricultural land is suitable for extensive grazing (DAFF, 2012). Cattle production has increased by 37 ooo heads from 13.50 million in 2004 to 13.87 million in 2011. At the same time areas for grazing declined due to expanding human settlements and other activities such as mining, crops, forestry, and conservation (DAFF, 2012). Commercial farmers and $40 \%$ by emerging and communal farmers own approximately 60 per cent of the 14.10 million cattle available in South Africa. The gross value of beef production is dependent on the number of cattle slaughtered and the prices received by farmers from abattoirs. The average gross value of beef produced in South Africa during the period 2001-02 until 2010-11 amounted to R9 960994 (DAFF, 2012). DAFF (2012) indicated that the beef industry is a 
major employer with 500000 people employed and 2125000 depending on the livestock farming industry for their livelihood.

High-value agricultural goods are defined as agricultural goods with a high economic value per kilogram, per hectare or calories, such as fruits, vegetables, eggs, milk, fish, and meat (Gulati et al., 2005). A high-value agricultural market implies that it is a better-paying market that generates high income/profit to farmers. According to the literature, the participation of South African emerging beef farmers in highvalue agricultural markets is unsatisfactory. It may be easy to access the market but retaining one's position in the market is more difficult particularly for South African emerging beef farmers (Ohen et al., 2014). Antwi et al. (2016) add that there are two types of markets namely, informal and formal. Informal markets embrace unofficial transactions among farmers and from farmers directly to consumers. On the other hand, formal markets have clearly defined grades, quality standards and safety regulations and prices are formally set. Smallholder farmers find it difficult to access these formal markets (Sikwela, 2013).

However, access to markets is an essential requirement for poor farmers in rural areas if they are to enjoy the benefits of agricultural growth. Rural people in many parts of the world and South Africa often indicate that they cannot improve their living standards because of their inability to access markets. They struggle to secure high-value agricultural markets because of their lack of understanding of the market structures and channels. Mangisoni (2006) argues that smallholder farmers are constrained by high transaction costs, high risks, missing markets and lack of collective action in the marketing environment. Development and encouragement of smallholder farmers are imperative in addressing high levels of rural poverty in many developing countries, including South Africa. A major challenge for sustainable agricultural development in South Africa is the limited ability by previously disadvantaged farmers, e.g., emerging farmers, in accessing both viable local and international markets for their produce.

One of the major challenges affecting South African emerging farmers is their inability to access high-value markets for their agricultural products; hence, their produce is often lost after production due to spoilage. The participation of emerging farmers in high-value agricultural markets is unsatisfactorily low. Sehar (2018) noted that the marketing of livestock is a complicated system because many factors intervene in the process of a sale. Baloyi (2010) advised that the contributions of smallholder agriculture to economic development could be realized if farmers are linked to high-value markets in the agricultural supply chain. According to Bienabe et al. (2004), agriculture is increasingly becoming integrated and smallholder farmers are often disadvantaged, and strategies to help them draw profit from their integration into markets are urgently required. Great changes have been noticed in the demand for high-value agricultural products, along with more stringent food safety and quality requirement and the emergence of supply chain integration. All these changes continued to affect and cause many farmers not to engage in finding high-value agricultural markets for their produce. Several studies revealed that smallholder and emerging farmers can be linked to markets, but they have failed to provide a solution to their inability to access high-value markets. Emerging farmers of Umjindi Local Municipality are not exempted from these challenges. The farmers are limited in participation and access to high-value agricultural markets. Their limited participation in high-value agricultural markets results in their inability to graduate into commercial farming. There has been no research done in the province to analyse emerging beef farmers' access to highvalue agricultural markets and its impact on livestock production especially using the treatment effect model. This study focuses on constraints hindering high-value agricultural market access, the market/channel and lastly, the impact of the participation on the livestock production and thus, suggests possible strategies to improve high-value agricultural market participation.

Consequently, it recommends possible strategies to increase the participation of emerging beef farmers in high-value agricultural markets at Umjindi Local Municipality. The significance of the study is to assist the emerging farmers to access high-value agricultural markets. If these challenges are well addressed, the emerging beef farmers from the Umjindi Local Municipality should become one of the leading marketing producers in the Mpumalanga Province. Furthermore, market information is expected to improve emerging beef farmers' market participation, hence that would enable them to make better-informed decisions and to negotiate for better selling prices. Similarly, the outcome of the research can serve as a blueprint to be adopted by other farmers, researchers and stakeholder in different regions. The results of the study will hopefully serve as a basis for policymakers to make informed decisions to improve emerging farmers' access to high-value agricultural markets.

\section{Materials and Methodology}

\section{The study area}

The study was carried out in the Umjindi Local Municipality in Ehlanzeni District, together with Nkomazi, Thaba Chweu, Mbombela and Bushbuckridge Municipalities in the Mpumalanga province, South Africa (Fig. 1). The district covers an area of $1,745.39 \mathrm{~km}^{2}$ (SALGA, 2010). The municipal area is situated within $25^{\circ} 47^{\prime} \mathrm{S}$ and $31^{\circ} \mathrm{O} 3^{\prime} \mathrm{E}$ geographical coordinates in the Lowveld Region. Barberton is the biggest 
town in the municipality and has its origin in the 1880's gold rush in the region. It is situated in the De Kaap Valley and is fringed by the Mkhonjwa Mountains. It is $43 \mathrm{~km}$ south of Nelspruit and $360 \mathrm{~km}$ to the east of Johannesburg (SALGA, 2010). The economy of Umjindi is dominated by agriculture, forestry, mining, and tourism. The region is well situated to agricultural development due to its unique geology and associated soil types, as well as rich biodiversity and an ideal climate.

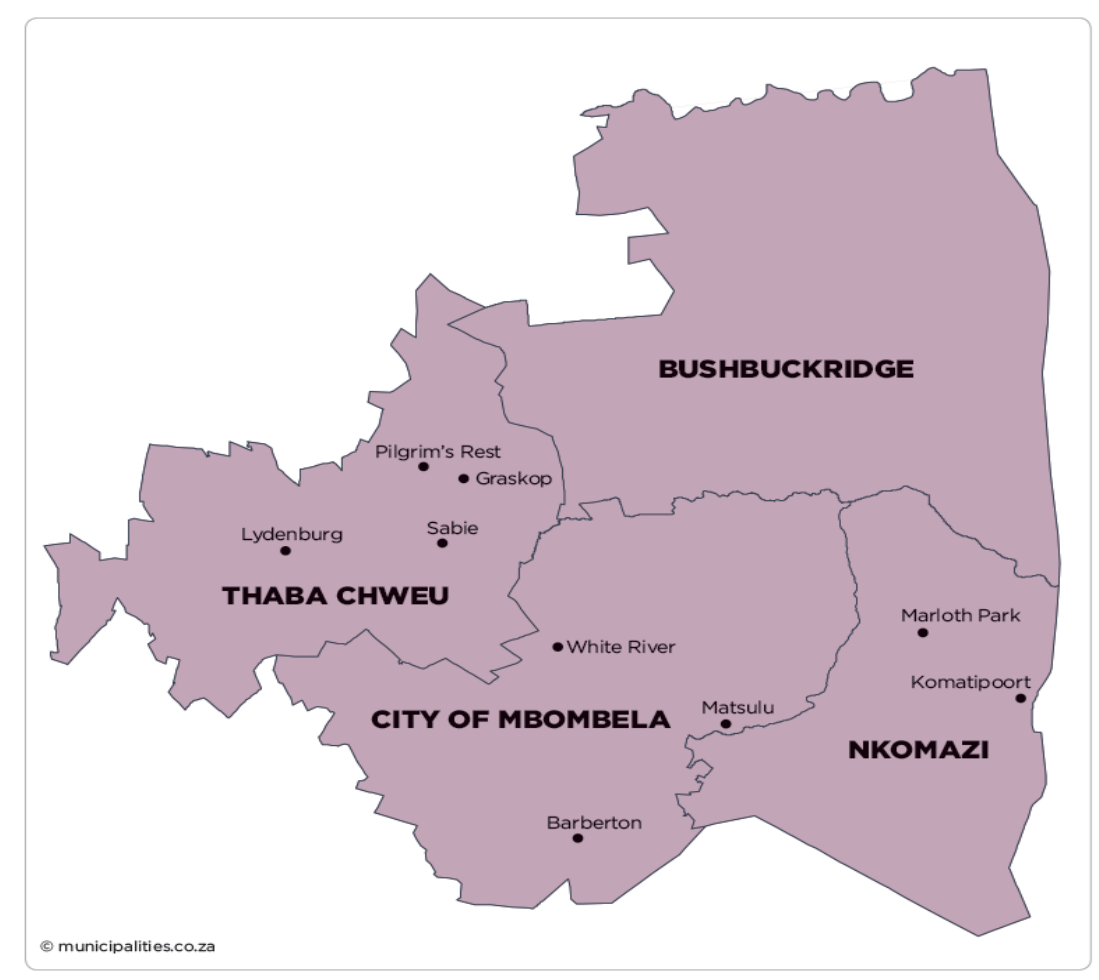

Fig. 1. Map of Umjindi Local Municipality of the Mpumalanga Province.

Source: https://municipalities.co.za/map/1146/umjindi-local-municipality

Umjindi Local Municipality was selected for this study to analyse the emerging beef farmers' to access the high-value agricultural market because it falls under the African Swine Fever (ASF) controlled areas or free zone. It is a Foot and Mouth Disease (FMD) free zone, and therefore emerging beef farmers from this municipality are free to sell their cattle anywhere in the country including the high-value markets without any valid veterinary movement permit or restriction of movement. The market prices for cattle in FMD free zones are favourably high to benefit farmers. This is supported by a study conducted by Hasler et al. (2017) in Rukwa, who found Kilyamatundu as one of the biggest primary markets in Sumbawanga rural with the following seasonal marketing patterns.

\section{Sampling procedure and sample size}

Systematic random probabilistic sampling method was used to obtain the required sample. A total of 55 emerging beef farmers formed the sample, which was selected from the eight identified villages. One high-value beef market was purposefully selected based on the vast knowledge possessed regarding the beef industry.

Data collection: The data were collected through face-to-face interviews with the co-operative beneficiaries and individual emerging beef farmers. The questionnaire was developed and used as the main data collection tool. The questionnaire used reflect information on the accessibility of high-value markets to emerging farmers. The interview schedule was constructed in two forms, namely structured and semistructured questions that the questionnaire was pretested and validated to avoid ambiguities and misinterpretation of the questions on the questionnaires. The study made use of both primary and secondary data.

Data analytical techniques: To ensure accuracy, consistency, and uniformity, the data collected was edited, coded and cleaned. The data were analysed using Stata to achieve the objectives accordingly. Descriptive statistics such as means, median, minimum and maximum values, frequencies, percentages, and standard deviations were used to describe the socioeconomic characteristics of the emerging beef farmers in Umjindi Local Municipality. Equally, a treatment effect model using propensity score matching estimator, fitted with logit model was used to analyse factors that influence access to high-value agricultural markets, as well as the impact of the participation on cattle production (cattle sold) in the study area. 
Model specification: The Propensity Score Matching (PSM) was principally used to compare two groups of subjects (treatment and control group). The propensity score is a probability and ranges in values from o to 1 . Since the two groups are comparable on all observed characteristics. The estimated propensity score, for subject $e\left(x_{i}\right)$, $(i=1 \ldots, N)$ is the conditional probability of being assigned to a treatment given a vector of observed covariates $x_{i}$ (Rosenbaum and Rubin, 1983).

$$
\begin{aligned}
& e\left(x_{i}\right)=\operatorname{Pr}\left(z_{i}=1 \mid \mathrm{x}_{\mathrm{i}}\right) \\
& \operatorname{Pr}\left(Z_{i}, \ldots, X_{1}, \ldots X_{n}\right)=\sum_{i=1}^{N} e\left\{X_{i}\right\}^{Z i}\{1-e\{X\}\}^{1-Z i}
\end{aligned}
$$

Where,

$Z_{i}=1$ for high value market

$z_{i}=0$ for non-high value market

$x_{i}=$ the vector of observed covariates for the $i^{\text {th }}$ subject

Following Rubhara et al. (2020), the study used PSM to investigate the impact of participation in a high-value market on cattle production (the number of cattle sold was used as a proxy). Propensity score values are dependent on a vector of observed covariates that are associated with the receipt of treatment. PSM entails forming matched sets of two groups of subjects who share a similar value of the propensity score (Rosenbaum and Rubin, 1983). The technique allows one to estimate the average treatment score (Casimir and Tobi, 2011). The one-to-one matching approach is the most common method used in PSM techniques. In this study, the propensity score of the farmers with the highvalue market was first generated using a logit model in which the model is given as:

$$
P(X)=\operatorname{Pr}\{D=1 / X\}=E\{D / X\}
$$

Where,

$\mathrm{D}=(0,1)$ is the indicator of exposure to treatment characteristics (dependent variable)

That is, $\mathrm{D}=1$, if exposed to treatment and $\mathrm{D}=\mathrm{O}$ if not exposed to treatment.

$\mathrm{X}$ is the multidimensional vector of observed characteristics (explanatory variables).

These explanatory variables are those which are expected to jointly determine the probability to participate in the treatment and the outcome.

Furthermore, after the propensity score is estimated and the nearest neighbour matching method was used. Nearest neighbour matching uses the propensity score of similar individuals in the two groups to construct the causal effect. The matching estimator is given as:

$\tau^{M}=\frac{1}{N^{T}} \sum_{i \in T}\left\{Y_{i}^{T}-\right.$

$\left.\sum_{j \in C} w_{i j} Y_{j}^{C}\right\}$

$=\frac{1}{N^{T}}\left\{\sum_{i \in T} Y^{T}-\sum_{i \in T} \sum_{j \in C} w_{i j} Y_{j}^{C}\right\}$

$i \in T$ by $N_{i}^{C}$ denotes the numbers of controls matched with observation and define the weights, $w_{i j=\frac{1}{N_{i}^{C}}}$ if $j \in C(i)$ and $w_{i j}=0$ otherwise.

$M$ stands for nearest neighbour matching and the number of units in the treated group is denoted by $\mathrm{N}^{\mathrm{T}}$.

Lastly, the average treatment effect, based on the predicted propensity scores $(\operatorname{Pr}(\mathrm{X}))$, was estimated. The impact of the participation is given by:

$$
\Delta=\mathrm{Y}_{1}-\mathrm{Y}_{0}
$$

The matched sample was used to compute the Average Treatment Effect for the treated (impact). It is estimated as follows:

$$
\mathrm{ATT}=\mathrm{E}(\Delta \mid \mathrm{D}=1, \mathrm{X})=\mathrm{E}\left(\mathrm{Y}_{1}-\mathrm{Y}_{\mathrm{o}} \mid \mathrm{D}=1, \mathrm{X}\right)
$$

$=\mathrm{E}\left(\mathrm{Y}_{1} \mid \mathrm{D}=1, \mathrm{X}\right)-\mathrm{E}\left(\mathrm{Y}_{\mathrm{O}} \mid \mathrm{D}=1, \mathrm{X}\right)$

Where, $\mathrm{D}=1$ denotes program participation (treatment) and $\mathrm{X}$ is a set of conditioning variables on which the subjects were matched. Equation 6 would have been easy to estimate except for the equation $\mathrm{E}\left(\mathrm{Y}_{\mathrm{O}} \mid \mathrm{D}=1, \mathrm{X}\right)$. This is the mean of the causal effect and denotes the outcome that would have been among participants had they not participated in the program. Given that the Conditional Independence Assumption and the common support assumption holds, then we estimate the mean effect of the treatment through the mean difference in the outcomes of the matched pairs:

$\mathrm{ATT}=\mathrm{E}\left[\mathrm{Y}_{1} \mid \mathrm{D}=1, \mathrm{P}(\mathrm{X})\right]=\mathrm{E}\left[\mathrm{Y}_{\mathrm{o}} \mid \mathrm{D}=\mathrm{o}, \mathrm{P}(\mathrm{X})\right](9)$

Where,

ATT is the average treatment effect of the treated, $\mathrm{D}=1$, is the treated group.

The ATE the average effect of the treatment for each farmer in the population is given as:

$A T E=\frac{N_{1}}{N} \times A T T+\frac{N_{0}}{N} \times A T U$

Where, $\mathrm{N}_{1}$ is the number of the treatment group and $\mathrm{N}_{\mathrm{o}}$ is the number of the control group. The equation above displays the relationship between ATT (average treatment on the treated), ATE (average treatment effect on an individual) and ATU (average treatment on the untreated).

Similarly, Tobit regression model was specifically used to analyse the factors, which influence the number of markets/channels in the study area where farmers sold their cattle. Most of the farmers in the study sell their cattle in different types of available market channels. The use of probability models is conceptually preferable to conventional linear regression models in the analysis of levels of outcome variables because parameter estimates from the former overcome most weaknesses of linear probability models namely: providing estimates which are asymptotically consistent and efficient. The general model is a model involving the estimation of the probability of a given set of indicators $\left(\mathrm{Y}_{\mathrm{i}}\right)$ as a function of a vector of explanatory variables $\left(\mathrm{X}_{\mathrm{i}}\right)$. 
The Tobit regression model, a hybrid of the discrete and continuous models. As with Logit and Probit models, the estimation of a Tobit model is greatly dependent on the underlying distribution of the error term in the latent variable model. Therefore, in the estimation of the Tobit model, it is assumed that the error term has a normal distribution. The model is expressed in equation 1 below.

$$
\begin{aligned}
& Y_{i}=\left\lceil y_{i}^{*}=\beta X_{i}+u_{i} \quad \text { if } y_{i}^{*}>0\right. \\
& =\mathrm{o}, \quad \text { if } \mathrm{y}_{\mathrm{i}}{ }^{*} \leq \mathrm{O} \\
& \mathrm{y}_{\mathrm{i}}^{*}=\beta \mathrm{X}_{\mathrm{i}}+\mathrm{u}_{\mathrm{i},} \quad \mathrm{N}\left(\mathrm{o}, \sigma^{2}\right)
\end{aligned}
$$

Where, $\mathrm{i}=$ number of respondents i.e. $(1,2 \ldots$.

The observable variable $Y_{i}$ is defined to be equal to the latent variable whenever the latent variable is above zero and zero otherwise.

$\mathrm{Y}_{\mathrm{i}}^{*}=$ number of markets where the farmer sells cattle out of the eight available markets.

$\mathrm{y}_{\mathrm{i}}^{*}>0$ implies that $\mathrm{y}_{\mathrm{i}}^{*}$ is observed.

$\mathrm{y}_{\mathrm{i}}{ }^{*} \leq \mathrm{O}$ implies that $\mathrm{y}_{\mathrm{i}}^{*}$ is not observed (a or $\mathrm{O}=$ limit).

$\mathrm{X}_{\mathrm{i}}$ is a vector of explanatory/independent variables.

$B$ is a vector of unknown coefficients and

$\mathrm{u}_{\mathrm{i}}$ is an independently normally distributed error term.

It can be shown that

$\mathrm{E}[\mathrm{y} / \mathrm{x}]=\Phi(\alpha) \mathrm{a}+(1-\Phi(\alpha))(\mu+\sigma \lambda(\alpha))$

Where $\alpha=(a-\mu) / \sigma, \lambda(\alpha)=\varnothing(\alpha) /(1-\Phi(\alpha))$,

$\mu=\beta \mathrm{x}$ and $\varnothing$ and $\Phi$ are the standard normal density and distribution functions respectively. $\lambda(\alpha)$ is called the inverse Mills ratio. Therefore, the marginal effects are:

$$
\begin{aligned}
& \partial \mathrm{E}\left[\mathrm{y}^{*} / \underline{\mathrm{x}}\right] / \partial \underline{\mathrm{x}}=\underline{\beta} \text { and } \\
& \partial \mathrm{E}[\mathrm{y} / \underline{\mathrm{x}}] / \partial \underline{\mathrm{x}}=\underline{\beta} \Phi((\underline{\underline{\mathrm{x}}-\mathrm{a}) / \sigma) .}
\end{aligned}
$$

It is worth mentioning that the marginal effect on $\mathrm{E}\left[\mathrm{y}^{*} / \mathrm{x}\right]$ is the usual formula for a linear model, but the marginal effect on the mean of the

Table 1. Variables used in the model. censored variable $y$ is a positive multiple of $\underline{\beta}$. In deriving the log likelihood function for the censored regression model, it is assumed that the limit value $\mathrm{a}=\mathbf{O}$, (censored at $\mathbf{0}$ ).

$\operatorname{In} \mathrm{Y}=-1 / 2 \sum_{1}\left(\operatorname{In}(2 \Pi)+\operatorname{In}\left(\sigma^{2}\right)+\left(\mathrm{y}_{\mathrm{i}}-\beta \mathrm{x}_{\mathrm{i}}\right)^{2} / \sigma^{2}\right)$ $+\sum_{\mathrm{o}} \operatorname{In}\left(1-\Phi\left(\mathrm{x}_{\mathrm{i}} / \sigma\right)\right)$

Where, the first sum $\sum_{1}$ is over the noncensored observations and the second sum $\sum_{0}$ is over the censored observations.

The Stata Version 16 (Statistical Programme) was used to analyse the limited dependent variable model in equation 11 and the parameter estimates for the effects of the independent variables on the number of markets where farmers sold their cattle were determined. The iterations were "Normally exited". The parameters estimated included the intercept, the estimates (coefficients), standard error, t-values and approximate $\operatorname{Pr}>t$. If the relationship parameter $\beta$ is estimated by regressing the observed $y_{i}$ on $x_{i}$, the resulting ordinary least square estimator is inconsistent. Amemiya (1985) has proven that the likelihood estimator for the Tobit model is consistent. The independent variables considered in the model are defined in the Table below. The possible number of markets/channels available to the emerging beef farmers was nine. This includes the following:

1=Abattoir

2=Informal market

$3=$ Local traders

$4=$ Speculators

$5=$ Auction

$6=$ Auction \& Informal market

$7=$ Local traders \& Auction

8=Local traders \& informal market

9=Abattoirs, Informal market and Auction

\begin{tabular}{|c|c|c|c|}
\hline ID & Independent variables & Variable label & Expected sign \\
\hline 1 & Gender of Farmer & Female $=1 ;$ Male $=0$ & -ve \\
\hline 2 & Age of farmer & Continuous & $+\mathrm{ve}$ \\
\hline 3 & House-Hold size & Continuous & $+\mathrm{ve}$ \\
\hline 4 & Years of farming & Continuous & $+\mathrm{ve}$ \\
\hline 5 & Land size & Continuous & $+\mathrm{ve}$ \\
\hline 6 & Total no. of cattle owns by farmer & Continuous & $+\mathrm{ve}$ \\
\hline 7 & Vaccinate cattle & Dichotomous $\mathrm{Yes}=1, \mathrm{No}=\mathrm{O}$ & +ve \\
\hline 8 & Receive feeds & Dichotomous $\mathrm{Yes}=1, \mathrm{No}=\mathrm{O}$ & $+\mathrm{ve}$ \\
\hline 9 & Have other sources of income & Dichotomous $\mathrm{Yes}=1, \mathrm{No}=\mathrm{O}$ & + ve \\
\hline 10 & Receive DARD lease assistance & Dichotomous $\mathrm{Yes}=1, \mathrm{No}=\mathrm{O}$ & $+\mathrm{ve}$ \\
\hline 11 & Sell cattle & Dichotomous $\mathrm{Yes}=1, \mathrm{No}=\mathrm{O}$ & +ve \\
\hline 12 & Market info. access & Dichotomous Yes $=1, \mathrm{No}=\mathrm{O}$ & $+\mathrm{ve}$ \\
\hline 13 & Difficult access high-value market & Dichotomous Yes $=1, \mathrm{No}=\mathrm{O}$ & $+\mathrm{ve}$ \\
\hline 14 & Mkt participation Satisfaction & Dichotomous Yes $=1, \mathrm{No}=0$ & $+\mathrm{ve}$ \\
\hline 15 & The role played in NERPO & Dichotomous $\mathrm{Yes}=1, \mathrm{No}=\mathrm{O}$ & -ve \\
\hline 16 & Grade's standards knowledge & Dichotomous $\mathrm{Yes}=1, \mathrm{No}=\mathrm{O}$ & $+\mathrm{ve}$ \\
\hline
\end{tabular}

An index was developed to constitute the dependent variable Yi as several channels used by the farmers from the maximum number of channels available.

Source: Survey data (2019). 


\section{Results and Discussion}

The descriptive statistics such as percentage, frequency, mean and standard deviation revealed the socioeconomics and farm-based characteristics of the beef farmers. Results from descriptive statistics revealed that the majority $(81.8 \%)$ of farmers had access to market information. About $36.4 \%$ of the farmers sold their cattle in high-value agricultural markets, whilst the majority (63.6\%) of farmers sold cattle through informal markets. About $76.4 \%$ of farmers had other markets closer to their farming businesses although they were not necessarily supplying these markets. A plausible explanation for this could be that they did not meet the market requirements. The results further indicated that $89.1 \%$ of farmers did not know the quality standards required by high-value agricultural markets, whereas $10.9 \%$ had slight knowledge. Additionally, 54.5\% of farmers showed that they found it challenging to access a high-value agricultural market with 45.5\% otherwise.

Table 2. Socioeconomics and farm-based characteristics in Umjindi local municipality.

\begin{tabular}{|c|c|c|c|c|}
\hline Variables & Minimum & Maximum & Mean & Std Deviation \\
\hline Cattle owned & 2 & 200 & 23.290 & 29.860 \\
\hline land Size & 0.5 & 500 & 276.482 & 100.065 \\
\hline Number of years & 1 & 32 & 10.150 & 8.076 \\
\hline Age & 22 & 95 & 57.000 & 17.271 \\
\hline Household size & 3 & 17 & 5.560 & 2.706 \\
\hline \multirow{2}{*}{\multicolumn{5}{|c|}{$\begin{array}{l}\text { Variables } \\
\text { Gender Head }\end{array}$}} \\
\hline & & & & \\
\hline \multicolumn{3}{|l|}{ Female } & 17 & 30.9 \\
\hline \multicolumn{3}{|l|}{ Male } & 38 & 69.1 \\
\hline \multicolumn{5}{|c|}{ Access to veterinary services } \\
\hline \multicolumn{3}{|l|}{ Yes } & 55 & 100.0 \\
\hline \multicolumn{3}{|l|}{ No } & 0 & 0.0 \\
\hline \multicolumn{5}{|c|}{ Access to feeds from government } \\
\hline \multicolumn{3}{|l|}{ Yes } & 52 & 94.5 \\
\hline \multicolumn{3}{|l|}{ No } & 3 & $5 \cdot 5$ \\
\hline \multicolumn{5}{|c|}{ Access to market information } \\
\hline \multicolumn{3}{|c|}{ Yes } & 45 & 81.8 \\
\hline \multicolumn{3}{|l|}{ No } & 10 & 18.2 \\
\hline \multicolumn{5}{|c|}{ Difficulties encountered when accessing high-value agricultural } \\
\hline \multicolumn{3}{|c|}{ Yes } & 30 & 54.5 \\
\hline \multicolumn{3}{|l|}{ No } & 25 & $45 \cdot 5$ \\
\hline \multicolumn{5}{|c|}{ Farmer's knowledge of grades and quality standards } \\
\hline \multicolumn{3}{|c|}{ Yes } & 49 & 89.1 \\
\hline \multicolumn{3}{|l|}{ No } & 6 & 10.9 \\
\hline \multicolumn{5}{|c|}{ Distribution of market activities Selling } \\
\hline \multicolumn{3}{|l|}{ Yes } & 40 & 72.7 \\
\hline \multicolumn{3}{|l|}{ No } & 15 & $27 \cdot 3$ \\
\hline \multicolumn{5}{|c|}{ High-value market } \\
\hline \multicolumn{3}{|c|}{ Yes } & 20 & 36.4 \\
\hline \multicolumn{3}{|l|}{ No } & 35 & 63.6 \\
\hline \multicolumn{5}{|c|}{ Other market closers } \\
\hline \multicolumn{3}{|c|}{ Yes } & 42 & 76.4 \\
\hline \multicolumn{3}{|l|}{ No } & 13 & 23.6 \\
\hline
\end{tabular}

Source: Survey data (2019), $n=55$

PSM Result: The results of the first part of the PSM which explored the logit model indicated that the age of the farmer was statistically significant $(\mathrm{Z}=-\mathbf{2 . 1 2})$ and had a negative influence on market participation among the emerging beef farmers in the study area. Thus, other factors held constant, the increase in age of farmers decreases their participation in the high-value markets. This may be because old farmers would find it difficult to understand the grades, standards and rules to comply within the highvalue markets. The result is contrary to that of Siziba et al. (2011) who found that the age of farmer has a strong positive effect on the likelihood of small-scale livestock farmers marketing their sheep to the mainstream markets such as abattoirs and auctions. However, the result is consistent with that of Cheteni and Mokhele (2019) who recorded a negative coefficient about project participation in mainstream markets. In this case, older project managers were unwilling to participate in sheep markets based on their risk-averse behaviour. It should be noted that age influence in mainstream market participation has been greatly debated in the literature, and scholars and researchers agree that the influence can be positive and negative, based on other factors. 
The results also indicate that the Household size of the farmer was statistically significant $(Z=-$ 1.92) and had a negative influence on market participation among the emerging beef farmers in the study area. Thus, other factors held constant, an increase in the household size of farmers decreases their participation in the high-value markets. This may be because large household sizes may be using some of the animals for home consumption reducing the number of animals available for the high-value market. The second money to be used to improve the herd of cattle may be used to cater for the needs of the members of the large household. The results further indicate that the Years of farming was statistically significant $(\mathrm{Z}=2.47)$ and had a positive influence on market participation among the emerging beef farmers in the study area. Thus, other factors held constant, an increase in years of farming of farmers increases their participation in the high-value markets. This may be due to experience gained in farming which may be used to improve the quality of the animals required at the high-value markets. The result is similar to that of Cheteni and Mokhele (2019) Who found that farming experience/number of years of farming have a strong positive effect on the likelihood of small-scale livestock farmers marketing their sheep to the mainstream markets such as abattoirs and auctions.

The results again indicate that difficulty accessing a high-value market was statistically significant $(\mathrm{Z}=1.98)$ and had a positive influence on market participation among the emerging beef farmers in the study area. Thus, other factors held constant, farmers who perceive that it is difficult to access high-value market increase their participation in the high-value markets. This may be farmers who strive to find out what it takes to enter the highvalue markets and their rewards as well and get motivated to meet the requirements and participate in it for the rewards.

Table 3. Factors that influence high-value market participation by the cattle farmers.

\begin{tabular}{|c|c|c|c|c|}
\hline High-value market & Coef. & Std. Err. & $\mathrm{Z}$ & $\mathrm{P}>|\mathrm{z}|$ \\
\hline Gender head & 0.3928 & 1.0093 & 0.39 & 0.697 \\
\hline Age & -0.1136 & 0.05370 & -2.12 & 0.034 \\
\hline Household size & -0.7794 & 0.4051 & -1.92 & 0.054 \\
\hline Years of farming & 0.2499 & 0.1011 & 2.47 & 0.013 \\
\hline Land size & 0.0033 & 0.0062 & 0.54 & 0.591 \\
\hline Total cattle number & 0.0463 & 0.0312 & 1.48 & 0.138 \\
\hline Other sources of income & -1.2750 & 1.5316 & -0.83 & 0.405 \\
\hline Dardlea assistance & -1.8731 & 2.1146 & -0.89 & 0.376 \\
\hline Market information access & 1.5849 & 1.3504 & 1.17 & 0.241 \\
\hline Difficulty accessing hvmrkt & 2.0540 & 1.0380 & 1.98 & 0.048 \\
\hline Grade's standards knowledge & -0.2222 & 1.2170 & -0.18 & 0.855 \\
\hline NERPO role & -0.1611 & 1.0529 & -0.15 & 0.878 \\
\hline constant & 3.7097 & 3.7983 & 0.98 & 0.329 \\
\hline
\end{tabular}

Source: Authors' computation (2021).

Note: ${ }^{* * *},{ }^{* *}$ and ${ }^{*}$ means significant at $1 \%, 5 \%$ and $10 \%$ significance levels, respectively.

Consequently, the treatment effect on average had a negative impact and decreases the highvalue market by 0.583 units, which implies that the high-value market decreases the number of cattle sold by $58.3 \%$. The result of the mean difference showed that there was a significant difference of 3.157 (with a t-value of 2.80) in the number of cattle sold between the high-value market and non-high value market. This could due to the quality and standard of the cattle required by the value market.

Table 4. Impact of high-value market participation on the number of cattle sold.

\begin{tabular}{|l|c|c|c|c|c|}
\hline Variable & Sample & Treated & Controls & Difference & T-stat \\
\hline Number of cattle sold & Unmatched & 5.10 & 1.943 & 3.157 & 2.80 \\
\hline
\end{tabular}

Source: Authors' computation (2021).

Note: ${ }^{* * *},{ }^{* *}$ and ${ }^{*}$ means significant at $1 \%, 5 \%$ and $10 \%$ significance levels, respectively.

Tobit Result: The Tobit estimates for the factors, which influence the number of markets/channels in the study area where farmers sold their cattle are presented in Table 5 below. The number of observations is 55; the LR chi $^{2}$ is 77.11 ; with the Prob > chi ${ }^{2}$ very significant (0.0000); a small Log-likelihood of -35.281719 ; and a false or Pseudo $\mathrm{R}^{2}$ of 0.5222 , which implies that even though pseudo, still indicates that $52.22 \%$ of the variation is explained by the variables in the model. Most of the estimates or coefficients associated with the explanatory variables have the expected parameter signs and three of the independent variables were found to be statistically significant at $1 \%$ and $5 \%$ levels of significance. It is worth mentioning that the signs of the estimates do not normally change between Ordinary Least Square Regression and Tobit model regression. What normally changes are the magnitudes and interpretation of the coefficients. 
A positive (negative) sign on an explanatory variable's coefficient indicates that other things being equal, higher values of the variable increase (decrease) the likelihood of it. The results indicate that four explanatory variables have a statistically significant influence on the number of markets/channels participated by the cattle farmers in the study area. The "Total no. of cattle owned" by farmer had a significant positive influence on the number of markets where the farmers' cattle were sold with all other factors held constant (coef. 0.0131023; std. error. $0.0034771 ;$ t-value $3.77 ; \quad \mathrm{P}>|\mathrm{t}| \quad 0.001)$. This implies that the markets/channels where the farmer sells cattle increases (1.3\%) with a unit increase in the number of cattle owned by the farmer. Thus, farmers with large herds of cattle sell their animals in the different available markets/channels in the study area for higher prices.

The results also show that the independent variable "Sell cattle" had a very significant positive influence on the number of markets/channels where the farmer sells cattle (coef. 1.991301; std error. 0.3118215; t-value 6.39; $\mathrm{P}>|\mathrm{t}|$ 0.000). Normally farmers who sell their cattle are commercially oriented and will prefer to sell their cattle in the appropriate markets/channels, which offers good value/better price. With all things being equal, the independent variable "DARD lease assistance" had a statistically significant negative influence on the number of markets where the farmer sells cattle (coef. -0.912801; std error $0.369093 ;$ t-value -2.47; $\mathrm{P}>|\mathrm{t}| \mathrm{0.018})$. This implies that a unit increase in "DARD lease assistance" to the farmer would lead to a $91 \%$ decrease in the number of markets where the farmer would like to sell cattle. All things being equal the DARD assistance is expected to improve the herd size and quality of stock; hence, farmers may be motivated to reduce the number of sales options and mainly target the high-value market for better profit.

Similarly, the independent variable "household size" had a statistically significant negative influence on the number of markets where the farmer sells cattle (coef. -0.080; std error 0.043; $\mathrm{t}$-value -1.86; $\mathrm{P}>|\mathrm{t}| \mathrm{0.070})$. This implies that a unit increase in the member of the household size would result in an $8 \%$ decrease in the number of markets where the farmer would like to sell cattle. This implies that a smaller household size lifts a burden off the household head, and he/she can search and explore many different market opportunities to sell.

Table 5. Factor influencing the number of markets/channels used by the cattle farmers.

\begin{tabular}{|c|c|c|c|c|}
\hline Variables & Coef. & Std. Err & $\mathrm{t}$ & $P>|t|$ \\
\hline Gender & -0.174 & 0.194 & -0.90 & 0.376 \\
\hline Age & -0.010 & 0.008 & -1.22 & 0.228 \\
\hline Household size & -0.080 & 0.043 & -1.86 & 0.070 \\
\hline Years of farming & 0.008 & 0.016 & 0.54 & 0.594 \\
\hline Land size & 0.000 & 0.001 & 0.14 & 0.887 \\
\hline Total cattle number & 0.013 & 0.004 & 3.77 & 0.001 \\
\hline Vaccination & -0.895 & 0.574 & -1.56 & 0.127 \\
\hline Receive feeds & 0.622 & 0.683 & 0.91 & 0.368 \\
\hline Other sources of income & -0.253 & 0.272 & -0.93 & 0.358 \\
\hline Dardlea assistance & -0.913 & 0.369 & -2.47 & 0.018 \\
\hline Sell cattle & 1.991 & 0.312 & 6.39 & 0.000 \\
\hline Access to market info & -0.315 & 0.347 & -0.91 & 0.369 \\
\hline Difficulty accessing H-V market & 0.012 & 0.227 & 0.05 & 0.960 \\
\hline Market participation satisfactory & 0.671 & 0.502 & 1.34 & 0.189 \\
\hline Nerporole & 0.040 & 0.213 & 0.19 & 0.851 \\
\hline Grade's standards knowledge & -0.379 & 0.286 & -1.32 & 0.194 \\
\hline Constant & 0.620 & 1.199 & 0.52 & 0.608 \\
\hline Var (e. market index) & 0.280 & 0.064 & & \\
\hline
\end{tabular}

Number of obs $=55$

Uncensored $=40$

Limits: lower $=0$ Left-censored $=15$ upper $=8$ Right-censored $=O$

$\operatorname{LR} \operatorname{chi}^{2}(16)=77.11$

Prob $>$ chi $^{2}=0.0000$

Log likelihood $=-35.281719$

Pseudo R2 = 0.5222

Source: Authors' computation (2021).

\section{Conclusion and Recommendation}

The study estimates the impact of high-value market participation on cattle production, the factors that influence high-value participation and the choice of market or channel choice in Umjindi local municipality, Mpumalanga Province of South Africa. The study concluded that access to the high-value agricultural market is greatly influenced by age of the farmers, household size, years of farming and difficulty accessing the high-value market. The impact of the participation of high-value market estimated using average treatment effect revealed that there was a negative impact in which a high-value market decreases the number of cattle sold by $58.3 \%$. The mean difference between the two 
groups (high-value market participation and nonhigh value market participation) showed that there was a significant difference of 3.157 (with a t-value of 2.80) in the number of cattle sold. Consequently, the market/channel in which farmers sells their cattle was influenced by household size, the total number of cattle, Dardlea assistance and if he/she sell cattle or not. It is, therefore, based on the results and to improve market access and high-value agricultural market participation, the following recommendations were made:

- The youth in the communities should be encouraged and provided with the necessary support to engage in beef cattle production. All things being equal, the youth may be adopting modern production skills better than the current very old beef cattle farmers in the study are many.

- Extension officers in the study area should motivate farmers with smaller household sizes to participate more in the high-value markets. All things being equal, it is expected that farmers with smaller household sizes can commit quite a substantial amount of their incomes to improve their cattle projects than farmers with larger household sizes. With improved cattle, such farmers have the potential to enter some of the available highvalue markets.

- Appropriate training to be tailored to the farmers to help improve the quality and marketability of the cattle of the farmers in the study area. This can be incorporated and implemented in the training programme of extension officers in the study area who serve the beef farmers.

- Advisors serving the farmers should regularly educate the farmers about the requirements for entry into the high-value markets couple with the appropriate training and resource support.

- Agricultural advisors should encourage the beef cattle farmers to sell more cattle, as this will make them more commercial-oriented, reduce over-grazing and eventually get more attracted to the high-value markets; and strive to meet the required grades and standards.

- The DARD lease assistance should continue and should include the lease of more land. Such assistance will improve the cattle herd sizes and quality of the cattle which would make it possible for the farmers to focus on one market which should be the high-value markets.

- Farmers should be encouraged to keep farm record and information. Thus, intensive farmer education, appropriate training and resource support are recommended to turn around the situation.

\section{Acknowledgements}

The authors would like to extend their gratitude to farmers who participated in the survey, the anonymous reviewers who helped in improving the quality of this article and the University of South Africa for providing the fund for the research.

\section{References}

Amemiya, T. 1985. Tobit Models. Advanced econometrics. Cambridge, Mass: Harvard University Press. p. 384.

Anonymous. 2012. South Africa info Reporter, incorporating material from the South African Yearbook. Available from www.southafrica,info/about/geography/mpumal anga.htm. [Accessed: 11 September 2015].

Antwi, M.A., Mazibuko, N.V.E. and Chagwiza, C. 2016. Determinants of smallholder cattle farmers' access to high-value cattle markets in the Ngaka Modiri Molema District, South Africa. Indian J. Anim. Res. 51(4): 764-770. https://doi.org/10.18805/ijar.voiof.3804

Baloyi, J.K. 2010. An analysis of constraints facing smallholder farmers in the Agribusiness value chain: A case study of farmers in the Limpopo Province. MS Thesis, Department of Agricultural Economics Extension and Rural Development, Faculty of Natural and Agricultural Sciences, University of Pretoria. pp. 13-35.

Bienabe, E., Coronel, C., Le, Coq and Liagre, L. 2004. Linking smallholder farmer to markets: Lessons learned from literature review and analytical review of selected projects. Study Report, Final draft, March 2004. CIRAD \& IRAM. World Bank. pp. 1328.

Casimir, G.J. and Tobi, H. 2011. Defining and using the concept of household: A systematic review. Int. J. Consum. Stud. 35(5): 498506. https://doi.org/10.1111/j.1470-6431.2011.01024.x

Cheteni, P. and Mokhele, X. 2019. Small-scale livestock farmers' participation in markets: evidence from the land reform beneficiaries in the Central Karoo, Western Cape, South Africa. South African J. Agri. Ext. 47(1): 118136.

https://doi.org/10.17159/2413-3221/2019/v47n1a494

DAFF. 2012. A profile of the South African beef market value chain. Department of Agriculture, Forestry and Fisheries. pp. 1-53.

FAO. 2012. Sustainability Pathways. Livestock and landscapes. The Food and Agriculture Organization of the United Nations, Rome. pp. 13-16. Retrieved form

http://:www.fao.org/nr/sustainability/sustainabi lity-and-livestock. [Accessed: 6 July 2019]. 
FAO. 2019. FAO's role in animal production. The Food and Agriculture Organization of the United Nations, Rome. Available from http://www.fao.org/animal-production/en/. [Accessed: 6 July 2019].

Gulati, A., Minot, N., Delegado, C. and Bora, S. 2005. Growth in high-value agriculture in Asia and the Emergence of vertical links with farmers. Paper presented at the workshop "Linking Small-scale Producers to Market: Old and New Challenges" The World Bank, (15 December 2005). pp. 1-35.

Hasler, B., Queenan, K., Rushton, J. and Mlangwa, J. 2017. Cost-benefit and feasibility analysis for establishing a foot and mouth disease free zone in Rukwa Region in Tanzania. pp. 12-26. Online: http://www.rrafrica.oie.int/docspdf/en/2017/STDF_PPG_516 _CBA_FMD_Tanzania_FINAL.pdf. [Accessed: 20 May 2019].

Mangisoni, J. 2006. Markets, Institutions and Agricultural Performance in Africa. ATPS special paper series No. 27, the African Technology Policy Studies Network, Nairobi. pp. 2-9. Retrieved from http://www.atpsnet.org/content/files/document s/pdf. [Accessed: 20 May 2017].

Markelova, H., Meinzen-Dick, R., Hellin, J. and Dohrn, S. 2009. Collective action for smallholder market access. Food Policy. 34(1): 1-7. https://doi.org/10.1016/j.foodpol.2008.10.001

Ohen, S.B., Umeze, G.E. and Cobham, M.E. 2014. Determinants of market participation by cucumber farmers in Odukpani Local Government Area, Cross River State Nigeria. J. Econ. Sust. Dev. 5(2): 54-62.
Rosenbaum, P.R. and Rubin, D.B. 1983. The central role of the propensity score in observational studies for causal effects. Biometrika. 70(1): 41-55. https://doi.org/10.1093/biomet/70.1.41

Rubhara, T.T., Mudhara, M., Oduniyi, O.S. and Antwi, M.A. 2020. Impacts of cash crop production on household food security for smallholder farmers: A case of Shamva District, Zimbabwe. Agric. 10(5): 188. https://doi.org/10.3390/agriculture10050188

SALGA. 2010. Umjindi Municipality: LED Strategy 2010-2013. South African Local Government Association. pp. 3-34.

Sehar, M. 2018. Factors influencing market access and livestock market inefficiency in Mpumalanga Province, South Africa. MS Thesis, Department of Agriculture, University of South Africa. pp. 6-32.

Sikwela, M.M. 2013. The impact of farmer support programmes on market access of smallholder farmers in the Eastern Cape and KwaZulu-Natal Provinces. PhD thesis, Department of Agricultural Economics and Extension Faculty of Science and Agriculture University of Fort Hare Alice. South Africa. pp. 190- 201.

Siziba S., Nyikahadozi, K., Diagne, A., Fatunbi, A.O. and Adekunle, A.A. 2011. Determinants of cereal market participation by subSaharan Africa smallholder farmer. J. Agric. Environ. Stud. 2(1): 181-191. 